\title{
Adaptation of cultured mussel Mytilus galloprovincialis Lamarck, 1819 from the northern Adriatic Sea to nearby aquaculture sites and translocation
}

\author{
Ines KOVAČIĆ ${ }^{1, *}$, Dijana PAVIČIĆ-HAMER ${ }^{1,2}$, Tjaša KANDUČ ${ }^{3}$ and Bojan HAMER ${ }^{1,2}$ \\ ${ }^{1}$ Marine Sciences, Juraj Dobrila University of Pula, Zagrebačka 30, 52100 Pula, Croatia \\ ${ }^{2}$ Center for Marine Research, Ruđer Bošković Institute, G. Paliaga 5, 52210 Rovinj, Croatia \\ ${ }^{3}$ Department of Environmental Sciences, Jožef Stefan Institute, Jamova cesta 39, 1000 Ljubljana, Slovenia \\ *Corresponding author, e-mail: ikovacic@unipu.hr
}

The ability of mussels to cope with environmental conditions depends on the species' capacity to acclimate or adapt within its morphometric and physiological parameters. In the present study, we investigated the effect of aquaculture site and translocation on different stocks of Mediterranean mussel, Mytilus galloprovincialis Lamarck, 1819. We used shell morphological ratios (width/length, height/length and height/width) and allometric relationships (volume-length and shell weight-length) in addition to condition index (wet meat weight/total weight) and mortality to compare cultivated and translocated mussels from the northern Adriatic Sea, Croatia. Mussels were collected from five cultivation areas (Lim, Pomer, Raša, Vabriga and Budava), and then moved for three months to experimental station at marine protected area in Lim Bay. Differences between cultivated mussels suggested morphological plasticity, although translocation weakly affected allometric relationships. Decrease in condition index was pronounced in translocated mussels, indicating adaptation to different local environmental conditions. High post translocation mortality was observed in mussels transferred to the experimental area. Our study shows plastic response of M. galloprovincialis, which can provide a useful information of mussel stocks selection in aquaculture.

Key words: Mytilus galloprovincialis, plasticity, adaptation, translocation

\section{INTRODUCTION}

Marine shellfish have become commercially very important species because of increasing global seafood consumption in recent years. Despite the high potential for aquaculture and the long tradition of the Croatian shellfish industry, it is based exclusively on two shellfish species; Mediterranean mussel and European flat oyster Ostrea edulis. Croatian shellfish farming is still small-scale and very traditional (BOGDANOVIĆ et al., 2014). The most important area of shellfish farming in northern Adriatic Sea is Lim Bay.
Translocation of mussels from natural spawning grounds to sites with favorable conditions for growth is practiced in numerous countries (FAO, 2015). Improvements in stocking strategy and management could increase the yield of mussels that are translocated from wild mussel resources and thereby enhance the sustainability of aquaculture. Understanding how marine bivalves respond to translocation and how rapidly new adaptations can evolve is key to predicting how mussels will respond to environmental changes.

The capacity of an individual to respond to a variety of stimuli (changing its physiology, 
behavior, synaptic connections, immune repertoire, etc.) in an adaptive direction is also called physiological adaptation, to be distinguished from evolutionary adaptation, the adaptive cross generational change in the composition of a population (GARLAND \& KELLY, 2006; FUSCO \& MINELLI, 2010). Examples of environmentally induced adaptive changes that occur within individual organisms during their lifetime is acclimatization due to translocation to new areas. Studies on morphological plasticity using shell morphometry and allometric relationships have been well documented from different regions of the world including mussel Mytilus edulis from Canada (ALUNNO-BRUSCIA et al., 2001; LAUZON-GUAY et al., 2005), Mytilus galloprovincialis from Spain (CUBILlO et al., 2012a; b), Parreysia favidens from India (MALIGAIAH \& SOLAI, 2015), and Hyriopsis (Limnoscapha) myersiana from Thailand (KOVITVADHI et al., 2008). Shell morphological ratios (width/length, height/length and height/width) are important basic data that show changes of shell proportions in wild (MOHAMMAD et al., 2015) or cultivated bivalves (ALUNNO-BRUSCIA et al., 2001) in various environmental conditions. The allometric relationships of weight-length (ALUNNO-BRUSCIA et al., 2001) and volume-length data (CUBILLO et al., 2012a) are also employed in physiological investigations to assess the well-being of individuals and to determine possible differences between separate unit stocks of the same species.

Adaptation involves a change in mussel weight, resulting in changes in condition index. The condition index is mainly used for two purposes: as a measure of the meat quality for the market, and as an ecophysiological measure of the health status of animals (PAVIČIĆ-HAMER et al., 2016). It summarizes the physiological activity of the organisms (growth, reproduction, secretion, stress, etc.) under given environmental conditions (LUCAS \& BENINGER, 1985). Variation in the condition index and meat yield of mussels may result from adaptations to differences of environmental conditions when mussels are translocated (PAMPANIN et al., 2005).

M. galloprovincialis is highly adaptable and especially tolerant of a wide range of environ- mental conditions. Extremes in physical factors such as storms, temperature, desiccation, and excessive deposition of silt are all known to cause mortality in mussels (SEED, 1992), especially during unusual extreme environmental conditions (HAMER et al., 2008). While predation is undoubtedly the single most important source of mussel mortality (KARAYÜCEL \& KARAYÜCEL, 2000), it may also be attributed to increased metabolic stress related to translocation, especially during extreme summer temperatures (YANICK et al., 2003).

The current study was carried out with two main aims:

1) to compare stocks of mussel, M. galloprovincialis from aquaculture sites in the Northern Adriatic by observing shell morphometric ratios (width/length, height/length and height/width), allometric relationships (volume-length, shell weight-length) and condition index and

2) to evaluate the mussel response to translocation from aquaculture sites to experimental area in Lim Bay. Gathered data about morphological plasticity, condition index and mortality after translocation could be useful for the purpose of mussel stock selecting and aquaculture planning.

\section{MATERIAL AND METHODS}

\section{Study area}

Cultivated mussels were collected from five farms in Istria (the northern Adriatic Sea, Croatia) (Fig. 1). Vabriga ( $\left.45^{\circ} 16^{\prime} 24^{\prime \prime} \mathrm{N} 13^{\circ} 34^{\prime} 57^{\prime \prime} \mathrm{E}\right)$ and Lim Bay $\left(45^{\circ} 07^{\prime} 50^{\prime \prime} \mathrm{N} 13^{\circ} 44^{\prime} 10^{\prime \prime} \mathrm{E}\right)$ are stations located on the western coast of the Istria. Lim Bay is the biggest cultivation area in Istria, and one of most important ones along the Croatian part of the Adriatic coast (HAMER et al., 2010). Lim Bay is the $10 \mathrm{~km}$ long estuary of the river Pazinčica, which plunges into the Lim channel-like bay. At the southernmost part of Istria is the cultivation area Pomer $\left(44^{\circ} 49^{\prime} 06^{\prime \prime} \mathrm{N}\right.$ $\left.13^{\circ} 54^{\prime} 09^{\prime \prime} \mathrm{E}\right)$. Budava (44⒊ $\left.34^{\prime} 35^{\prime \prime} \mathrm{N} 13^{\circ} 59^{\prime} 28^{\prime \prime} \mathrm{E}\right)$ and Raša $\left(45^{\circ} 01^{\prime} 13^{\prime \prime} \mathrm{N} 14^{\circ} 03^{\prime} \mathrm{E}\right)$ cultivation areas are located on the east coast of Istria. Lim Bay, Pomer and Budava are integrated aqua- 


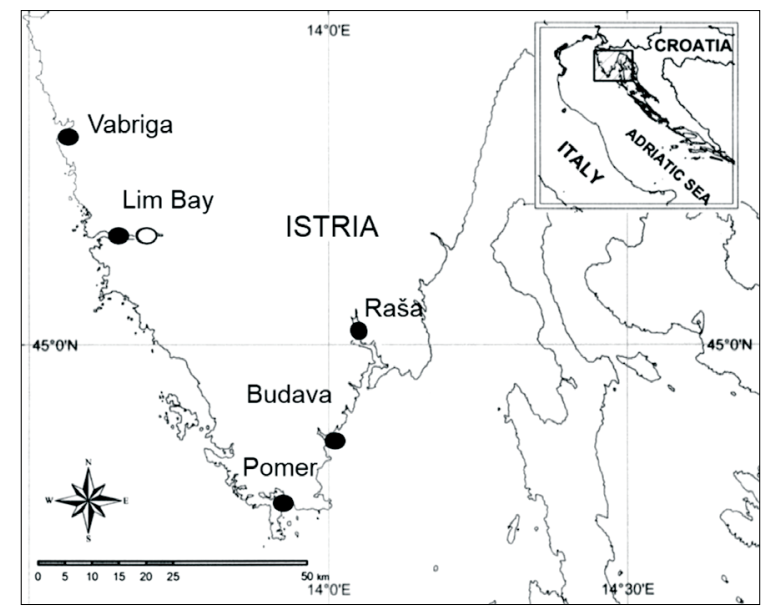

Fig. 1. Locations of the cultivation areas (black dots) and experimental station (white dot) in Istria (the northern Adriatic Sea, Croatia)

culture sites with mussels, European seabass Dicentrachus labrax and Gilthead seabream Sparus aurata (MARUŠIĆ et al., 2009).

\section{Experimental design}

Mussels were translocated from the five cultivation areas (Vabriga, Lim Bay, Pomer, Budava, and Raša) to an experimental station in marine protected of Lim, at the entrance to Lim Bay $\left(45^{\circ} 08^{\prime} 03^{\prime \prime} \mathrm{N}, 13^{\circ} 42^{\prime} 48^{\prime \prime} \mathrm{E}\right)$ from April to July 2010. Hundred mussels immersed in seawater $\left(11^{\circ} \mathrm{C}\right)$ were translocated in two hour from each cultivation area in cold boxes. Animals were placed into "experimental" nets con- structed from polyethylene bag and immersed on floats at $0.5 \mathrm{~m}$ depth. "Experimental" nets were placed into plastic cages $(80 \times 50 \times 50 \mathrm{~cm})$ in order to prevent mortality caused by predators. The experiment ended after 90 days in July and samples were transferred to the laboratory in cool boxes. Samples were observed for the presence of dead mussels (open shells).

In July, hundred mussel samples were also collected from each cultivation area and transported in cold boxes directly to the labo:atory and analysed to provide comparative results with the translocated mussels from Lim ( $\mathrm{N}=63)$, Pomer $(\mathrm{N}=73)$, Raša $(\mathrm{N}=71)$, Vabriga $(\mathrm{N}=75)$ and Budava $(\mathrm{N}=87)$.

The salinity and water temperature were measured with pIONneer 65 instrument (Radiometer Analytical S.A., Villeurbanne, France) in situ at each station during the sampling (Table 1).

\section{Sampling procedure}

From each mussel sample, length (L; maximum distance of the antero-posterior axis), width (W; maximum lateral axis) and height $(\mathrm{H}$; maximum distance of the dorso-ventral axis) of the shells were measured using a $0.05 \mathrm{~mm}$ precision calliper. These measurements were used to calculate the shell morphological ratios: $\mathrm{W} / \mathrm{L}, \mathrm{H} / \mathrm{L}$ and $\mathrm{H} / \mathrm{W}$. The volume of mussels was determined using direct water displacement in $500 \mathrm{~mL}$ graduated cylinders. After each mussel

Table 1. Temperature $\left({ }^{\circ} \mathrm{C}\right)$ and salinity $(g L-1)$ at the cultivated areas and experimental area in April and July 2010

\begin{tabular}{lllllll}
\hline & \multicolumn{2}{l}{ Temperature $\left({ }^{\circ} \mathrm{C}\right)$} & \multicolumn{3}{c}{ Salinity $\left(\mathrm{gL}^{-1}\right)$} \\
Area & $\begin{array}{l}\text { Cultivated } \\
\text { April }\end{array}$ & $\begin{array}{l}\text { Experimental } \\
\text { July }\end{array}$ & $\begin{array}{l}\text { Cultivated } \\
\text { April }\end{array}$ & $\begin{array}{l}\text { Cultivated } \\
\text { April }\end{array}$ & $\begin{array}{l}\text { Experiment } \\
\text { July }\end{array}$ & $\begin{array}{l}\text { Cultivated } \\
\text { April }\end{array}$ \\
\hline Lim & 12.20 & 22.80 & 27.30 & 14.73 & 30.30 & 33.20 \\
Raša & 13.30 & - & 25.10 & 30.10 & - & 35.70 \\
Budava & 11.00 & - & 25.00 & 30.00 & - & 35.70 \\
Vabriga & 11.00 & - & 26.00 & 25.00 & - & 34.20 \\
Pomer & 11.10 & - & 26.20 & 34.52 & - & 36.80 \\
\hline
\end{tabular}


was weighed for total weight (TW), the tissue was removed from the shell and total wet meat weight (WMW) and shell weight (SW) were weighed individually.

We assumed an allometric relationship between volume - length (V-L) and shell weight - length (SW-L) of mussels. These allometries were established for each mussel group using equations:

$\log \mathrm{V}=\mathrm{a}+\mathrm{b} \log \mathrm{L}$ and $\log \mathrm{SW}=\mathrm{a}+\mathrm{b} \log \mathrm{L}$ where $\mathrm{a}$ - is intercept and $\mathrm{b}$ - is slope (allometric coefficient).

Condition index (CI) was calculated (HICKMAN \& ILLINGWORTH, 1980) using the equation:

$\mathrm{CI}(\%)=\mathrm{WMW}(\mathrm{g}) \times 100 / \mathrm{TW}(\mathrm{g})$.

Mortality (M) was determined using the equation (STIRLING \& OKUMUŞ, 1994):

$$
\mathrm{M}(\%)=100(\mathrm{Nt} / \mathrm{N} 0)
$$

where $\mathrm{N}_{\mathrm{t}}$ - is the number of empty shells removed from the cage after $\mathrm{t}$ - time and $\mathrm{N}_{0}$ - is the number of mussels at the beginning.

\section{Data analysis}

All data analyses were calculated using the Statistica 6.0 software. Analysis of variance (factorial ANOVA) was used to determine the effect of the cultivation areas, treatment and their interaction on width/length (W/L), height/ length $(\mathrm{H} / \mathrm{L})$ and height/width $(\mathrm{H} / \mathrm{W})$ ratios. Under homogeneity of variance (Levene test, $\mathrm{p}>0.05$ ), parametric ANOVA followed by a Tukey-HSD (Honest Significant Difference) test were performed. Analysis of variance (factorial ANOVA) was used to determine the effect of the cultivation area, treatment and their interaction on condition index. As the heterogeneity of variance (Levene test; $p<0.05$ ) for condition index (WMW/TW) was found, a Kruskal -Wallis test, followed by Mann - Whitney test for pairwise comparison was performed. Analysis of covariance (ANCOVA) was applied to determine the treatment effect between mussels from each cultivation area on the log transformed data relationship of volume-length (V-L) and shell weight-length (SW-L).

\section{RESULTS}

\section{Environmental factors}

In April, temperatures at the investigated sites ranged between 11.00 and $13.00{ }^{\circ} \mathrm{C}$ (Table 1). In July, temperature increased seasonally and varied between 25.00 at $27.20^{\circ} \mathrm{C}$ in mariculture areas. Salinity was characterized by numerous site variations (Table 1). The salinity in April ranged from $14.73 \mathrm{gL}^{-1}$ in Lim Bay to 34.52 $\mathrm{gL}^{-1}$ in Pomer. The rise of salinity was observed in all mariculture areas in July. The salinity in July ranged from $33.20 \mathrm{gL}^{-1}$ in Lim Bay to 36.80 in Pomer. In the experimental area of Lim Bay, a temperature of $22.80{ }^{\circ} \mathrm{C}$ and salinity of 30.30 $\mathrm{gL}^{-1}$ were measured in July.

\section{Morphometry}

Shell length (mean \pm SD) of cultivated mussels was $67.63 \pm 3.13 \mathrm{~mm}$ and translocated mussels $66.78 \pm 3.73 \mathrm{~mm}$ in July. No significant differences in initial length values were observed between cultivated and translocated mussels (ANOVA; $p>0.05$ ).

Cultivation area showed a significant effect on the $\mathrm{W} / \mathrm{L}$ ratio (ANOVA, $\mathrm{p}<0.05$ ) (Table 2 ). The lowest $\mathrm{W} / \mathrm{L}$ ratio in translocated mussels was observed in mussels from Lim Bay farm when compared to mussels from Budava, Pomer and Vabriga ( $\mathrm{t}$ - test, $\mathrm{p}<0.05$ ) (Fig. 2). While there was a tendency for increase in this ratio in translocated mussels (except for mussels translocated from the Lim Bay farm to the experimental station), this increase was statistically insignificant as treatment showed no effect on the $\mathrm{W} / \mathrm{L}$ ratio. The significant interaction between cultivation area and treatment variables revealed a variable effect on the $\mathrm{W} / \mathrm{L}$ ratio (ANOVA, $\mathrm{p}<0.05$ ) (Table 2).

Cultivation area showed a significant effect on the $\mathrm{H} / \mathrm{L}$ ratio (ANOVA, $\mathrm{p}<0.05$ ). Cultivated mussels from Raša had a significantly lower $\mathrm{H} / \mathrm{L}$ ratio than mussels from Budava and Pomer (t test, $\mathrm{p}<0.05$ ) (Fig. 2). While there was a tendency for $\mathrm{H} / \mathrm{L}$ ratios to decrease in translocated mussels (except mussels translocated from Lim Bay farm), this decrease was statistically 
KovAČIĆ et. al.: Adaptation of cultured mussel Mytilus galloprovincialis Lamarck, 1819 from the northern... 289

Table 2. Two-way ANOVA results testing the influence of cultivation areas and translocation on width/length (W/L), height/ length $(H / L)$ and height/width $(H / W)$ ratios for mussels

\begin{tabular}{lllll}
\hline Source of variation & df & S.S. & M.S. & F \\
\hline W/L & & & & \\
Area & 4 & 0.007 & 0.002 & $3.66^{*}$ \\
Translocation & 1 & $8 \times 10^{-4}$ & $8 \times 10^{-4}$ & 1.69 \\
Area x Translocation & 4 & 0.008 & 0.002 & $4.30^{*}$ \\
H/L & & & & \\
Area & 4 & 0.026 & 0.006 & $8.40^{*}$ \\
Translocation & 1 & $3 \times 10^{-5}$ & $3 \times 10^{-5}$ & 0.04 \\
Area x Translocation & 4 & 0.003 & $7 \times 10^{-4}$ & 0.90 \\
H/W & & & & \\
Area & 4 & 0.282 & 0.070 & $5.88^{*}$ \\
Translocation & 1 & 0.010 & 0.010 & 0.90 \\
Area x Translocation & 4 & 0.193 & 0.048 & $4.01^{*}$ \\
\hline
\end{tabular}
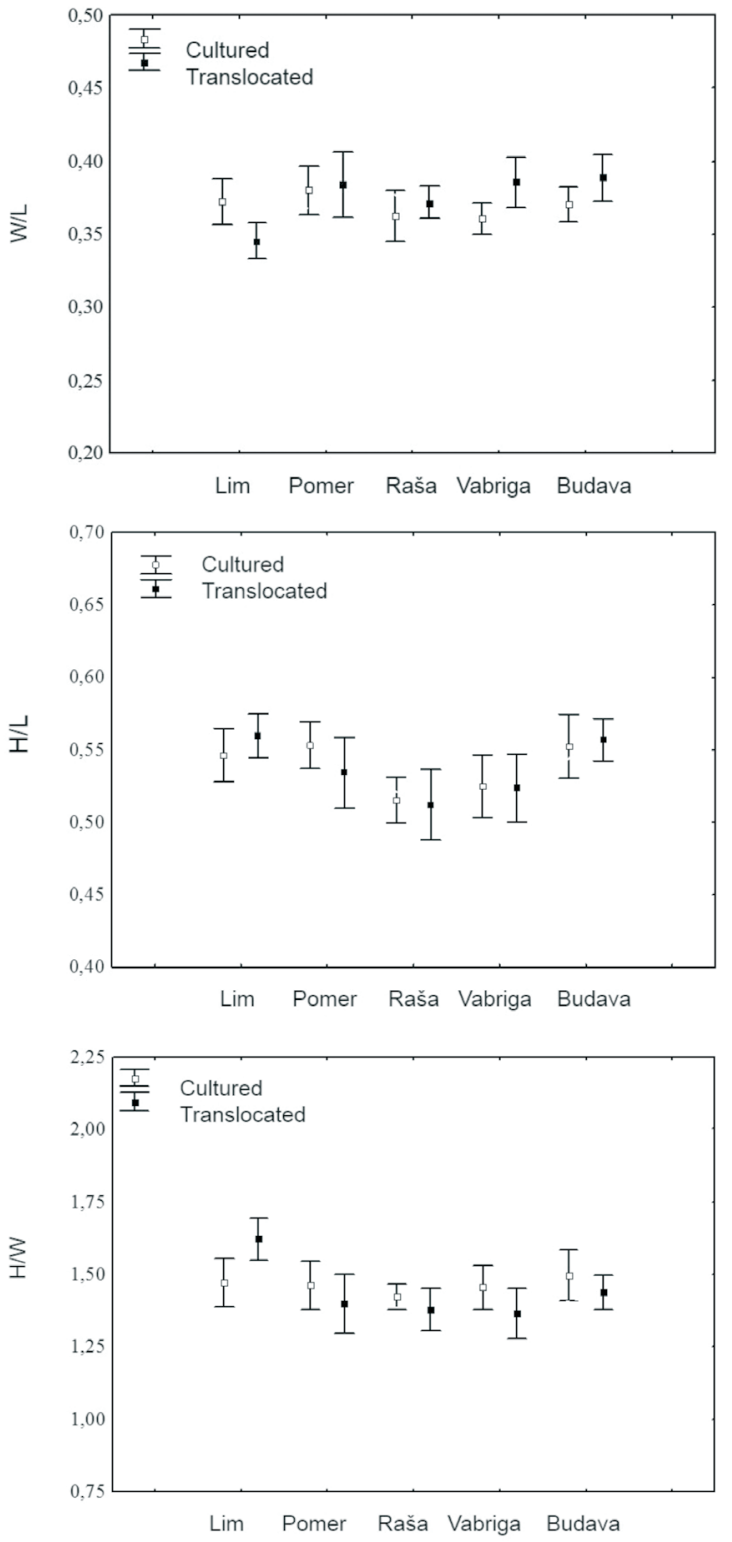

no effect on $\mathrm{H} / \mathrm{W}$ ratio (Table 2). The significant interaction between cultivation area and treatment variables revealed a variable effect on the $\mathrm{H} / \mathrm{W}$ ratio.

\section{Allometry}

The V-L relationship in cultivated mussels was similar for all areas (Fig. 3). The lowest V-L relationship was observed in mussels cultured in Pomer and highest in Vabriga. V-L relationship in translocated mussels decreased in mussels from Raša, Budava and Vabriga, and increased in mussels translocated from Lim and Pomer. However, treatment showed no significant effect on the V-L relationship (ANCOVA, $\mathrm{p}>0.05$ ) (Table 3).

SW-L relationship in cultured and translocated mussels was similar for all mussels (Fig. 3). The lowest SW-L relationship was observed in mussels cultured in Budava and highest in Pomer. SW-L relationship in translocated mussels was decreased in translocated mussels from Pomer, Raša and Vabriga. An increased SW-L relationship in translocated mussels was detected in mussels moved from Lim and Budava. However, treatment showed no significant effect on the SW-L relationship (ANCOVA, $\mathrm{p}>0.05$ ) (Table 3).

Fig. 2. Morphological ratios (mean $\pm S D$ ) of the cultured (open symbols) and translocated (filled symbols) mussels: Width / Length ratios (W/L); Height / Length $(H / L) ;$ Height / Width $(H / W)$ 
Table 3. ANCOVA results testing the influence of translocation on volume-length $(V-L)$ and shell weight - length $(S W-L)$ relationship in mussels

\begin{tabular}{lllll}
\hline & df & S.S. & M.S. & F \\
\hline Lim & & & & \\
V-L & 1 & 0.255 & 0.255 & 4.293 \\
SW-L & 1 & $6 \times 10^{-4}$ & $6 \times 10^{-4}$ & 0.505 \\
Pomer & & & & \\
V-L & 1 & 0.004 & 0.004 & 2.399 \\
SW-L & 1 & $7 \times 10^{-4}$ & $7 \times 10^{-4}$ & 0.175 \\
Raša & & & & \\
V-L & 1 & $5 \times 10^{-4}$ & $5 \times 10^{-4}$ & 0.180 \\
SW-L & 1 & 0.142 & 0.142 & 0.090 \\
Vabriga & & & & \\
V-L & 1 & $7 \times 10^{-6}$ & $7 \times 10^{-6}$ & 0.059 \\
SW-L & 1 & 0.008 & 0.008 & 3.624 \\
Budava & & & & \\
V-L & 1 & $2 \times 10^{-4}$ & $2 \times 10^{-4}$ & 0.650 \\
SW-L & 1 & $1 \times 10^{-4}$ & $1 \times 10^{-4}$ & 0.048 \\
\hline
\end{tabular}
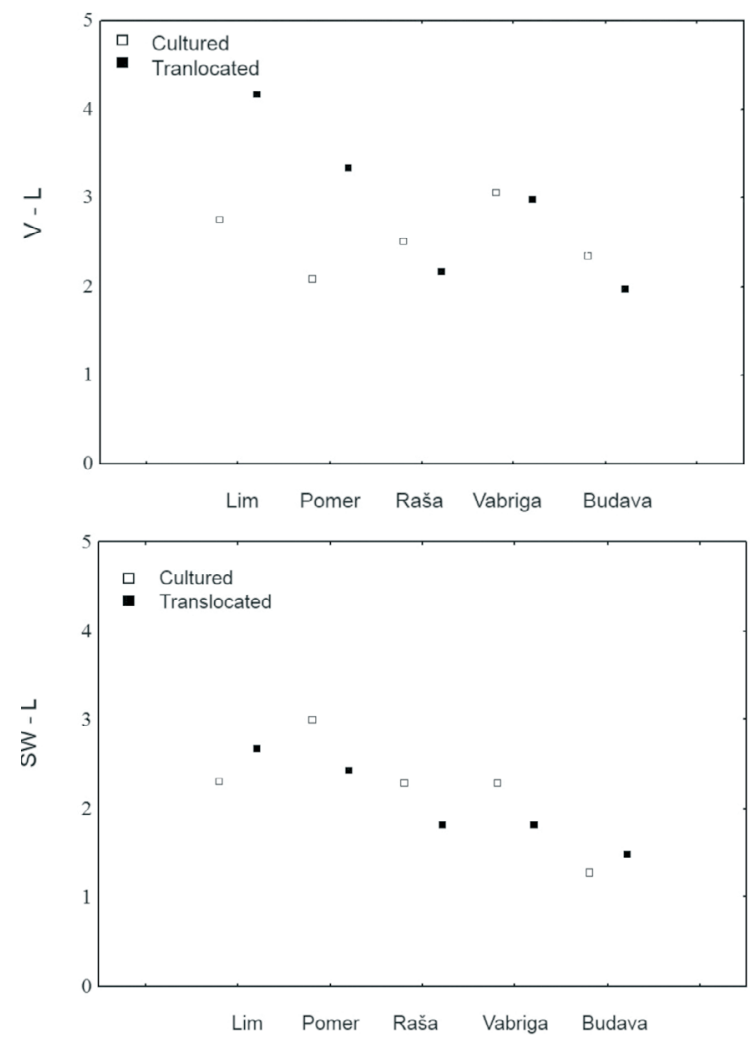

Fig. 3. Slope values of the allometric relationship for cultured (open symbols) and translocated (filled symbols) mussels: Volume - Length (V-L); Shell Weight - Length (SW-L)

\section{Condition index}

The highest CI of cultured mussels was observed in mussels from Budava with significant difference from Raša, Pomer and Vabriga (Mann Whitney, $\mathrm{p}<0.05$ ) (Fig. 4). In translocated mussels, a common tendency of a decrease in CI was observed in mussels translocated from all cultivation areas, except the Lim Bay farm. The highest $\mathrm{CI}$ in translocated mussels was observed in mussels moved from the Lim Bay farm to the experimental station (Mann Whitney, $\mathrm{p}<0.05$ ).

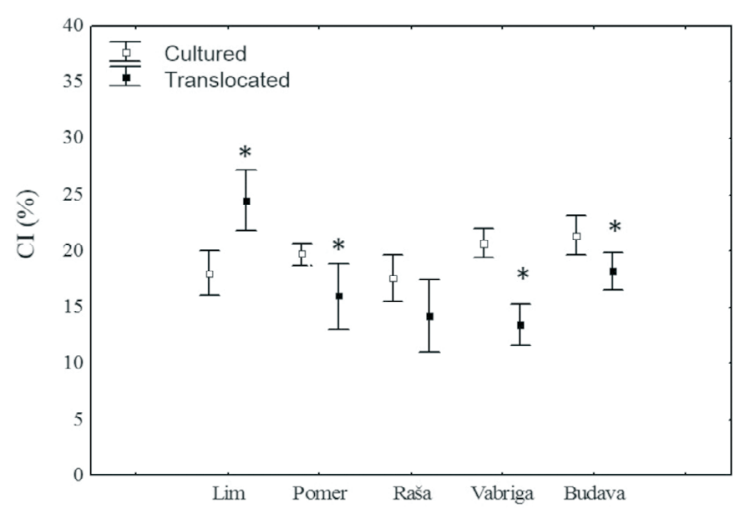

Fig. 4. Condition index (CI) (mean $\pm S D)$ of cultured (open symbols) and translocated (filled symbols) mussels. Asterisks (*) indicate significant difference between cultured and translocated mussels $(p<0.05)$

\section{Mortality}

Translocation had a marked effect on mussel mortality (Fig. 5). Mussels moved from Lim cultivation area to experimental station had the

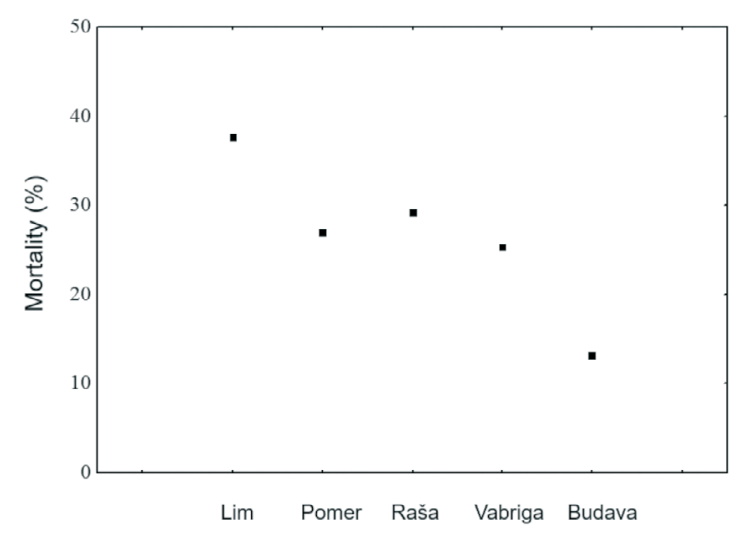

Fig. 5. Mortality of translocated mussels $(\%, N=100)$ 
highest mortality (37.66\%), which is followed by Raša (29.16\%), Pomer (27.00\%) and Vabriga $(25.39 \%)$. The lowest mortality was observed in mussels translocated from Budava (13.13\%).

\section{DISCUSSION}

We observed different response of cultured mussel stocks in the northern Adriatic Sea. The effect of translocation on mussel morphology was weak in mussels moved from farms to the experimental station. However, the translocated mussels showed a slight decrease in the $\mathrm{H} / \mathrm{W}$ ratios and increase in $\mathrm{W} / \mathrm{L}$ ratio, except mussels translocated from central Lim Bay to experimental station. Our results agree with previous studies of morphological variations in mussels, showing less circular and more dorso-ventrally elongated mussels in cultivation areas (ALUNNOBRUSCIA et al., 2001; LAUZON-GUAY et al., 2005). This morphological change offers advantages in a crowded environment by allowing mussels to grow for a longer time prior to being physically restrained by neighboring individuals (LAUZONGUAY et al., 2005). The morphological changes observed in the mussels cultivated at farms could be a strategy to reduce physical interference between individuals, which may cause a reduction in valve gaping, clearance rate and food uptake (RIISGARD, 2001).

The influence of cultivation area showed significant differences in morphological ratios, suggesting morphological plasticity of mussels. Morphological plasticity is a strategy to reduce the effect of intra-specific competition at the individual level (BROWN et al., 1976; CUBILLO et al., 2012a). There exists a controversy over the limiting factor in intra-specific competition mechanisms in bivalves. ALUNNO-BRUSCIA et al. (2001) suggested food availability as the greatest limitation, whereas OKAMURA (1986) attributed intra-specific competition mechanisms to physical spatial limitations.

In our study no translocation effect on the relationships of mussel V-L was observed as it was detected in the CUBILLO et al. (2012a) study. Individuals translocated to the experimental station from different farms occupied a similar volume and surface area as was detected in previous study of mussels. Moreover, we found little evidence for an effect of translocation on the SW-L relationship of mussels that could be explained with a short time of translocation period in which could be difficult to observe increase of shell weight. Shell weight increases slower than tissue weight, and is dependent on the size of the mussel stock sampled from different environments (LAUZON-GUAY et al., 2005).

The condition index of the mussel beside health status (well-being) indicator, can be interpreted as an index of growth (CAMACHO et al., 1995). YANICK et al. (2003) observed lower relative growth rates of mussels in translocation experiments, which is confirmed in our study. A simpler explanation accounting for the translocation effect might be the physiological adaptations of the mussels to the prevailing environmental conditions at the place of origin, as well as different physiological states at the beginning of the experiment. Both regional and local environmental parameters influence growth rate. Abiotic factors include water temperature and salinity, may affect the rates of biochemical reactions in organisms living in temperate latitudes. Feeding conditions can modify the physiological traits of mussels (BAYNE, 1976) and the differences may persist for several months, as suggested in translocation experiments (WIDDOWS et al., 1984; PAMPANIN et al., 2005). Despite the stress caused by translocation, mussels from cultivation areas in Istria maintained market size (meat content: 4-5 g and shell size $50-60 \mathrm{~mm}$ ) (KHAN et al., 2006) by July at experimental station with no further difference in biometrical parameters. Important factors in growth rate are particulate organic matter (TROOST et al., 2010) and local factors that determine nutritional conditions can greatly influence the growth rate of marine bivalves (YILDIZ et al., 2006; PEHARDA et al., 2007; ÇELIK et al., 2015). An increase in seawater temperature over the spring to summer season, followed by a decrease in salinity corresponds with the increase of plankton biomass and nutrient enrichment by freshwater influx in Lim Bay experimental station (HAMER et al., 2010). This is followed by an increase in condition index that 
reaching a maximum in summer as it was detected in several studies (GAREN et al., 2004; YILDIZ et al., 2006; ÇELIK et al., 2012; KARAYÜCEL et al., 2015). This study suggests that local seston depletion in the high harvesting period in Lim Bay (May - July) could diminish the translocation effect on condition index. Lim Bay is a moderately eutrophic area compared with the otherwise mainly oligotrophic coastal waters of the Adriatic (KARAYÜCEL et al. 2010). Moreover, this may have been due to the proximity of a European seabass Dicentrachus labrax and Gilthead seabream Sparus aurata aquaculture area located also in Lim Bay. The integrated aquaculture of bivalves with fish could provide a local trophic source as was detected in several other studies (PEHARDA et al. 2007, ŽUPAN et al. 2013; ŽUPAN et al. 2014). Several authors documented the close relationship between mussel growth efficiency and food availability, indicating that growth performance is limited by the energetic potential of available food (ALUNNO-BRUSCIA et al. 2001; LAUZON-GUAY et al. 2005). The present study provides experimental evidence of an important effect of area on mussel growth rate. This effect may originate from genetic differences among areas (CAMACHO et al., 1995), but previously we identified mussels along Adriatic coast as $M$. galloprovincialis by nuclear marker Me15/16 (HAMER et al., 2012). Moreover, the proximity of sampling stations (40 km distance) makes this hypothesis unlikely, as concluded by CAMACHO et al. (1995). Genetic differences might affect condition index only if seed from collector ropes or juveniles from local cultivation areas is affected by genetic factors. Several authors stated that cultivation area does not appreciably affect growth rate, while it does affect mortality (STIRLING \& OKUMUŞ, 1994; KRISTENSEN \& LASSEN, 1997; ÇELIK et al., 2009). This was also confirmed in our study. In general, natural mortality in mussel populations results from an interaction of many biological and physical factors (HAMER et al., 2008). In this study, increased mortality of mussel may be attributed to increased metabolic stress related to translocation. YANICK et al. (2003) showed that increased metabolic stress in mussels has been correlated with mortality of mussels. The mortality rate was higher in translocated mussels, particularly during the summer months (YANICK et al., 2003). The similar effect of mortality related to translocation was noted by ŽUPAN et al. (2014) for Noah'ark Arca noae in the Eastern Adriatic after transfer from natural sites to the cultivation site. Moreover, the combined effects of higher feeding rate and increased temperature from spring to summer may be responsible for mortality (ÇELIK et al., 2009). Increased mortality rates could occur during the summer months, possibly resulting in $40 \%$ mortality (KRISTENSEN \& LASSEN, 1997) which is supported by our study. Since shellfish aquaculture is typically located in estuarine areas or inshore coastal waters (KAISER et al., 1998; DANOVARO et al., 2004) it is likely that the remaining growth difference originated in factors like a different food quality and different physiological behavior (DEMERS \& GUDERLEY, 1994).

In summary, our study shows plastic response of M. galloprovincialis stocks in coping with translocation. Sampling area affected morphological ratios in mussels from cultivation areas, which suggest morphological plasticity of mussel stocks. Condition index was affected with translocation, resulting in lower levels in translocated mussels. Since difference in mortality of translocated mussel stocks was found, it should be taken into account when selecting mussel stock for planning and/or expanding aquaculture.

\section{ACKNOWLEDGMENTS}

This study was performed in the frame of the bilateral Slovenian-Croatian project "Tracing natural and anthropogenic influences to marine ecosystem along the Adriatic coast (Istrian peninsula) with Mediterranean mussel Mytilus galloprovincialis" (project number BI-HR/12-13037). Financial support for this paper was given by the Ministry of Science and Education of the Republic of Croatia and Slovenian Research Agency (P1-0143). The authors are grateful to Dr. Massimo DEVESCOVI for assistance with statistical analyses. 


\section{REFERENCES}

ALUNNO-BRUSCIA, M., E. BOURGET \& M. FRÉCHETTE. 2001. Shell allometry and lengthmass-density relationship for Mytilus edulis in an experimental food-regulated situation. Mar. Ecol. Prog. Ser., 219: 177-188.

BAYNE, B. L. 1976. Marine Mussels, Their Ecology and Physiology. Cambridge University Press.

BOGDANOVIĆ, T., I. UJEVIĆ, M. SEDAK, E. LISTEŠ, V. ŠIMAT, S. PETRIČEVIĆ \& V. POLJAK. 2014. $\mathrm{As}, \mathrm{Cd}, \mathrm{Hg}$ and $\mathrm{Pb}$ in four edible shellfish species from breeding and harvesting areas along the eastern Adriatic Coast, Croatia. Food Chem., 146: 197-203.

BROWN, R., R. SEED \& R. O'CONNOR. 1976. A comparison of relative growth in Cerastoderma (= Cardium) edule, Modiolus modiolus, and Mytilus edulis (Mollusca: Bivalvia). J. Zool., 179: 297-315.

CAMACHO, A. P., U. LABARTA \& R. BEIRAS. 1995. Growth of mussels (Mytilus edulis galloprovincialis) on cultivation rafts: influence of seed source, cultivation site and phytoplankton availability. Aquaculture, 138: 349-362.

ÇELIK, M. Y., S. KARAYÜCEL \& İ. KARAYÜCEL. 2009. Effects of environmental factors on growth and mortality of raft cultivated mussel (Mytilus galloprovincialis L.) cultivated in lantern nets in Black Sea. AACL Bioflux, 2: $97-108$.

ÇELIK, M. Y., S. KARAYÜCEL, İ. KARAYÜCEL, B. EYÜBOĞLU \& R. ÖZTÜRK. 2015. Settlement and growth of the mussels (Mytilus galloprovincialis, Lamarck, 1819) on different collectors suspended from an offshore submerged longline system in the Black Sea. Aquacult. Res., 1-12.

ÇELIK, M. Y., S. KARAYÜCEL, İ. KARAYÜCEL, R. ÖZTÜRK \& B. EYÜBOĞLU. 2012. Meat Yield, Condition Index, and Biochemical Composition of Mussels (Mytilus galloprovincialis Lamarck, 1819) in Sinop, South of the Black Sea. J. Aquat. Food Prod. Technol., 21: 198205.

CUBILlO, A. M., L. G. PETEIRO, M. J. FERNÁNDEZ-REIRIZ \& U. LABARTA. 2012a. Density- dependent effects on morphological plasticity of Mytilus gallloprovincialis in suspended culture. Aquaculture, 338-341: 246-252.

CUBILLO, A. M., L. G. PETEIRO, M. J. FERNÁNDEZREIRIZ \& U. LABARTA. 2012b. Influence of stocking density on growth of mussels (Mytilus galloprovincialis) in suspended culture. Aquaculture, 342-343: 103-111.

DANOVARO, R., C. GAMBI, G. M. LUNA \& S. MIRTO. 2004. Sustainable impact of mussel farming in the Adriatic Sea (Mediterranean Sea): evidence from biochemical, microbial and meiofaunal indicators. Mar. Poll. Bull., 49: 325-333.

DEMERS, A. \& H. GUDERLEY. 1994. Acclimatization to intertidal conditions modifies the physiological response to prolonged air exposure in Mytilus edulis. Mar. Biol., 118: 115-122.

FAO. 2015. National Aquaculture Sector Overview.

FUSCO, G. \& A. MINELLI. 2010. Phenotypic plasticity in development and evolution: facts and concepts. Philosophical Transactions of the Royal Society B: Biological Sciences, 365: 547-556.

GAREN, P., S. ROBERT \& S. BOUGRIER. 2004. Comparison of growth of mussel, Mytilus edulis, on longline, pole and bottom culture sites in the Pertuis Breton, France. Aquaculture, 232: 511-524.

GARLAND, T., JR. \& S. A. KELLY. 2006. Phenotypic plasticity and experimental evolution. J. Experim. Biol., 209: 2344-2361.

HAMER, B., Z. JAKŠIĆ, D. PAVIČIĆ-HAMER, L. PERIĆ, D. MEDAKOVIĆ, D. IVANKOVIĆ, J. PAVIČIĆ, C. ZILBERBERG, H. C. SCHRODER, W. E. MULLER, N. SMODLAKA \& R. BATEL. 2008. Effect of hypoosmotic stress by low salinity acclimation of Mediterranean mussels Mytilus galloprovincialis on biological parameters used for pollution assessment. Aqua. Toxicol., 89: 137-151.

HAMER, B., M. KORLEVIĆ, E. DURMIŠI, V. NERLOVIĆ \& N. BIERNE. 2012. Nuclear marker Me 15-16 analyses of Mytilus galloprovincialis populations along the eastern Adriatic coast. Cah. Biol. Mar., 53: 10. 
HAMER, B., D. MEDAKOVIĆ, D. PAVIČIĆ-HAMER, Ž. JAKŠIĆ, M. ŠTIFANIĆ, V. NERLOVIĆ, A. TRAVIZI, R. PRECALI \& T. KANDUČ. 2010. Estimation of freshwater influx along the eastern Adriatic coast as a possible source of stress for marine organisms. Acta Adriat., 51: 191194.

HICKMAN, R. W. \& J. ILLINGWORTH. 1980. Condition cycle of the green-lipped mussel Perna canaliculus in New Zealand. Mar. Biol., 60: 27-38.

KAISER, M. J., I. LAING, S. D. UTTING \& G. M. BURNELL. 1998. Environmental impacts of bivalve mariculture. J. Shellfish Res., 17: 59-66.

KARAYÜCEL, S. \& İ. KARAYÜCEL. 2000. The effect of environmental factors, depth and position on the growth and mortality of raft-cultured blue mussels (Mytilus edulis L.). Aquacult. Res., 31: 893-899.

KARAYÜCEL, S., M. Y. ÇELIK, İ. KARAYÜCEL, R. ÖZTÜRK \& B. EYÜBOĞLU. 2015. Effects of stocking density on survival, growth and biochemical composition of cultured mussels (Mytilus galloprovincialis, Lamarck 1819) from an offshore submerged longline system. Aquacult. Res., 46: 1369-1383.

KHAN, M. A., C. C. PARRISH \& F. SHAHIDI. 2006. Effects of environmental characteristics of aquaculture sites on the quality of cultivated Newfoundland blue mussels (Mytilus edulis). J. Agricult. Food Chem., 54: 2236-2241. KOVITVADHI, S., U. KOVITVADHI, P. SAWANGWONG, P. TRISARANUWATANA \& J. MACHADO. 2008. Morphometric relationship of weight and size of cultured freshwater pearl mussel, Hyriopsis (Limnoscapha) myersiana, under laboratory conditions and earthen pond phases. Aquacult. Int., 17: 57-67.

KRISTENSEN, P. S. \& H. LASSEN. 1997. The production of relaid blue mussels (Mytilus edulis L.) in a Danish fjord. ICES Journal of Marine Science: Journal du Conseil., 54: 854-865.

LAUZON-GUAY, J.-S., D. J. HAMILTON \& M. A. BARBEAU. 2005. Effect of mussel density and size on the morphology of blue mussels (Mytilus edulis) grown in suspended culture in Prince
Edward Island, Canada. Aquaculture, 249: 265-274.

LUCAS, A. \& P. G. BENINGER. 1985. The use of physiological condition indices in marine bivalve aquaculture. Aquaculture, 44: $187-$ 200.

MALIGAIAH, R. M. \& S. SOLAI. 2015. Morphometry, length-weight relationships and condition index of Parreysia favidens (Benson, 1862)(Bivalvia: Unionidae) from river Seeta in the Western Ghats, India. Ind. J. Fisher., 62.

MARUŠIĆ, N., S. VIDAČEK, H. MEDIĆ \& T. PETRAK. 2009. Index kondicije dagnji (Mytilus galloprovincialis) u uvali Budava i zaljevu Raša. Ribarstvo, 68: 19-25.

MOHAMMAD, Z., H. K. BAHRAM \& S. M. REZA. 2015. Allometry, condition index and secondary production in bivalve Barbatia decussata on rocky intertidal shores in the Northern Persian Gulf, Iran. J. Environ. Biol. / Academy of Environmental Biology, India, 36: 1185-1192.

OKAMURA, B. 1986. Group living and the effects of spatial position in aggregations of Mytilus edulis. Oecologia, 69: 341-347.

PAMPANIN, D. M., E. VOLPATO, I. MARANGON \& C. NASCI. 2005. Physiological measurements from native and transplanted mussel (Mytilus galloprovincialis) in the canals of Venice. Survival in air and condition index. Comp. Biochem. Physiol. Part A: Mol. Int. Physiol., 140: 41-52.

PAVIČIĆ-HAMER, D., I. KOVAČIĆ, L. KOŠČICA \& B. HAMER. 2016. Physiological Indices of Maricultured Mussel Mytilus galloprovincialis Lamarck, 1819 in Istria, Croatia: Seasonal and Transplantation Effect. J. World Aquacult. Soc., 47: 768-778.

PEHARDA, M., I. ŽUPAN, L. BAVČEVIĆ, A. FRANKIĆ \& T. KLANJŠČEK. 2007. Growth and condition index of mussel Mytilus galloprovincialis in experimental integrated aquaculture. Aquacult. Res., 38: 1714-1720.

RIISGARD, H. U. 2001. On measurement of filtration rates in bivalves-the stony road to reliable data: review and interpretation. Mar. Ecol. Prog. Ser., 211: 275-291. 
SEED, R., SUCHANEK, T.H. 1992. Titl., In: G. E. (Editor), The Mussel Mytilus: Ecology, Physiology, Genetics and Culture, 87-169.

STIRLING, H. P. \& İ. OKUMUŞ. ž Growth, mortality and shell morphology of cultivated mussel (Mytilus edulis) stocks cross-planted between two Scottish sea lochs. Mar. Biol., 119: 115-123.

TROOST, T. A., J. W. M. WIJSMAN, S. SARAIVA \& V. FREITAS. 2010. Modelling shellfish growth with dynamic energy budget models: an application for cockles and mussels in the Oosterschelde (southwest Netherlands). Philosophical Transactions of the Royal Society B: Biological Sciences, 365: 35673577.

WIDDOWS, J., P. DONKIN, P. SALKELD, J. CLEARY, D. LOWE, S. EVANS \& P. THOMSON. 1984. Relative importance of environmental factors in determining physiological differences between two populations of mussels (Mytilus edulis). Mar. Ecol. Prog. Ser.,

YANICK, J. F., J. W. HEATH \& D. D. HEATH. 2003. Survival and growth of local and transplanted blue mussels (Mytilus trossulus, Lamark). Aquacult. Res., 34: 869-875.

YILDIZ, H., M. PALAZ \& M. BULUT. 2006. Condition Indices of Mediterranean Mussels (Mytilus galloprovincialis L. 1819) Growing on Suspended Ropes in Dardanelles. J. Food Technol., 4: 221-224.

ŽUPAN I., J. ROGOŠIĆ, T. ŠARIĆ \& D. KANSKI. 2013. Transfer of Arca noae Linnaeus, 1758 from natural to different experimental farming conditions. Croat. J. Fisheries, 71: 187-191.

ŽUPAN I., M. PEHARDA, T. DOLENEC, M. DOLENEC, P.Ž. ROŽIČ, S. LOJEN, D. EZGETA-BALIĆ \& J. ARAPOV. 2014. Aquaculture assessment of Noah's Ark (Arca noae Linnaeus, 1758) in the Central Adriatic Sea (Croatia). J. Shellfish Res., 33: 433-441.

Received: 13 June 2017

Accepted: 30 September 2017 


\title{
Prilagodba uzgojne dagnje Mytilus galloprovincialis Lamarck, 1819 u sjevernom Jadranu na uvjete u uzgajalištu i translokaciju
}

\author{
Ines KOVAČIĆ,*, Dijana PAVIČIĆ-HAMER, Tjaša KANDUČ i Bojan HAMER \\ *Kontakt e-adresa: ikovacic@unipu.hr
}

\begin{abstract}
SAŽETAK
Sposobnost dagnji da se nose s uvjetima okoliša ovisi o sposobnosti vrste da se prilagodi svojim morfometrijskim i fiziološkim obilježjima. U ovom radu smo istražili prilagodljivost mediteranske dagnje Mytilus galloprovincialis Lamarck, 1819 u akvakulturi i tijekom premještanja na novu lokaciju. Pored morfoloških omjera: širina/dužina, visina/dužina i visina /širina i alometrijskih odnosa (volumen/dužina i masa školjkaša/dužina) koristili smo indeks kondicije (masa mokrog tkiva /ukupna masa) i mortalitet dagnje kako bi usporedili primjerke dagnje iz uzgajališta s onima koje su translocirane. Jedinke dagnje uzorkovane su u pet uzgojališta (Lim, Pomer, Raša, Vabriga i Budava), a zatim je dio premješten na tri mjeseca na eksperimentalnu postaju na zaštićenoj morskoj površini u Limskom zaljevu. Razlike između primjeraka dagnji iz uzgajališta sugeriraju morfološku prilagodljivost. Translokacija dagnji je slabo utjecala na alometrijske odnose. Smanjenje indeksa kondicije izraženo je u translociranim dagnjama, što ukazuje na prilagodbu različitim uvjetima okoline. Također, primijećen je i mortalitet dagnji koje su translocirane u Lim. Naše istraživanje pokazuje morfometrijski i fiziološki odgovor M. galloprovincialis, koji može pružiti korisne informacije o odabiru stoka dagnje u akvakulturi.
\end{abstract}

Ključne riječi: dagnja Mytilus galloprovincialis, prilagodba, translokacija 